\title{
Mineralogy and chemistry of banded iron formations (BIF) of Tiruvannamalai area, Tamil Nadu
}

\author{
N SUBBA REDDY and A N SASHIDHAR \\ Department of Geology, S.V. University, Tirupathi 517 502, India \\ MS received 5 February 1988; revised 23 January 1989
}

\begin{abstract}
The mineralogy and chemistry of banded iron formations (BIF) of Archaean high grade granulite gneiss belt of Tiruvannamalai area are presented here. The BIF of this area is chemically different from those around the world. The iron formations and associated granulites are of different origin namely metasedimentary and metavolcanic respectively.
\end{abstract}

Keywords. Banded iron formations; granulites; mineralogy; magnetite-quartzite.

\section{Introduction}

The banded iron formations (BIF) constitute one of the distinct and important components of Archaean schist belts of India. In southern India these formations occur both in granulite-gneiss and in greenstone belts. Although many workers have studied these BIF in detail, the Tiruvannamalai deposit has not received much attention. Based on the mineralogy and chemistry of the BIF and associated granulites their origin, source, and environment of formation as well as their similarities or differences with other precambrian BIF have been discussed. Prasad et al (1982) and Radhakrishna (1985) have classified the Indian BIF as follows:

$$
\begin{array}{ll}
\text { Region } & \text { Type of } \\
\text { BIF Age (Ma) }
\end{array}
$$

Proterozoic Iron ore series of Bihar and Orissa Superior 2500-1900

Archaean $\left\{\begin{array}{lll}\text { Greenstone belts } & \text { Algoma } & 2900-2500 \\ \text { High grade granulite gneiss belts } & \text { Tamil } & \\ \text { and Sargurs } & \text { Nadu } & <2900\end{array}\right.$

\section{Geology of Tiruvannamalai}

This area forms part of the Archaean high grade granulite-gneiss terrain of South India and contains rocks of diverse chemical and mineralogical compositions. BIF in these formations is mainly magnetite-quartzite associated with amphibolites, granulites, metapelites, sillimanite-quartz schists and pyroxenites. The surrounding rocks are granite gneiss and charnockites. These rocks have been subjected to high amphibolite to granulite facies metamorphism and have undergone folding, faulting and shearing. A series of dykes have been cut across the area in SE direction. Magnetite-quartzite occurring in the form of a single band is approximately $10-12 \mathrm{~km}$ 
long with a width of 10 to $40 \mathrm{~m}$. The band being comparitively harder stands out as prominent ridges.

\section{Methods of study}

Mineralogical and textural studies of magnetite-quartzite and associated granulites have been made on 29 thin sections and 15 polished ore mounts. Whole rock chemical analysis for 11 samples of magnetite-quartzite was carried out calorimetrically for major oxides using either a Spectornic 20 calorimeter or a Unicam-500 spectrophotometer. FeO was determined by titrimetric method.

\section{Mineralogy}

The two different mineral assemblages observed in the magnetite-quartzite in the order of abundance are: (i) Quartz-magnetite-orthopyroxene-clinopyroxene-apatitechlorite-actinolite-grunerite-martite and (ii) quartz-magnetite-orthopyroxene-garnetapatite-chlorite-hornblende-martite. Magnetite and quartz occur both in granular texure and banded forms with alternate layers of quartz and magnetite. The preservation of banding is conspicuous despite high grade metamorphism, but quartz shows strain, crushing or deformational effects. Fine hair-like cracks in quartz grains are seen filled with iron oxide. Small euhedral grains of hypersthene occur as inclusions within magnetite. They are found in different degrees of alteration giving rise to chlorite, actinolite and hornblende. The clinopyroxene has been identified as hedenbergite. Pink, deep red, or brown garnet is found occasionally. In a few sections apatite is noticed as minute needle-like crystals.

Under reflected light magnetite is grey in colour with brownish tinge. Characteristic octahedral and cubic parting planes are noticed. The cubic nature of the parting plane is indicated by means of triangular pits. Magnetite is martitized to different degrees. Reflectance of magnetite in air in green light ranges from 20.5 to $21.2 \%$. Vicker's hardness ranges from 600 to 625 at $50 \mathrm{~g}$ load but gradually decreases at higher loads.

Table 1. Chemical composition (wt. \%) of magnetite-quartzite of Tiruvannamalai area.

\begin{tabular}{|c|c|c|c|c|c|c|c|c|c|c|c|}
\hline & $V_{1}$ & $V_{2}$ & $V_{4}$ & $V_{6}$ & $V_{16}$ & $V_{23}$ & $V_{25}$ & $V_{22}$ & $V_{11}$ & $V_{34}^{r}$ & $V_{30}$ \\
\hline $\mathrm{SiO}_{2}$ & 47.01 & $46 \cdot 10$ & $42 \cdot 01$ & 48.84 & $47 \cdot 20$ & $43 \cdot 80$ & 48.08 & $47 \cdot 60$ & $44 \cdot 90$ & $37 \cdot 40$ & $46 \cdot 70$ \\
\hline $\mathrm{Al}_{2} \mathrm{O}_{3}$ & 0.50 & 0.16 & 0.30 & 0.20 & 0.30 & 0.25 & 0.62 & 0.10 & $0 \cdot 36$ & 0.57 & 0.68 \\
\hline $\mathrm{FeO}$ & 11.08 & $8 \cdot 30$ & 14.31 & $7 \cdot 21$ & 9.20 & 10.75 & $8 \cdot 86$ & $7 \cdot 20$ & 14.84 & $12-85$ & 7.85 \\
\hline $\mathrm{Fe}_{2} \mathrm{O}_{3}$ & $38 \cdot 80$ & $42 \cdot 40$ & 43.41 & $39 \cdot 48$ & $41 \cdot 20$ & $43 \cdot 48$ & $39 \cdot 40$ & $41 \cdot 30$ & $37 \cdot 80$ & 44.80 & $40 \cdot 50$ \\
\hline $\mathrm{CaO}$ & 0.11 & $1 \cdot 22$ & 0.36 & - & 0.40 & - & 0.30 & 0.90 & 0.63 & 0.23 & 0.42 \\
\hline $\mathrm{MgO}$ & 0.92 & 1.50 & $1 \cdot 29$ & $1 \cdot 27$ & 0.50 & 0.43 & $1 \cdot 15$ & 0.95 & $1 \cdot 26$ & $2-04$ & 1.80 \\
\hline $\mathrm{Na}_{2} \mathrm{O}$ & - & $0 \cdot 10$ & - & 0.30 & -- & $0 \cdot 21$ & - & $0 \cdot 10$ & 0.35 & 0.60 & 0.40 \\
\hline $\mathrm{K}_{2} \mathrm{O}$ & 0.10 & $0 \cdot 10$ & 0.40 & 0.20 & 0.20 & 0.10 & $0 \cdot 15$ & $0 \cdot 10$ & - & 0.15 & 0.48 \\
\hline $\mathrm{TiO}_{2}$ & 0.15 & 0.20 & - & 0.40 & 0.48 & 0.32 & 0.25 & 0.38 & 0.46 & 0.35 & 0.15 \\
\hline $\mathrm{MnO}$ & 0.20 & 0.21 & 0.22 & 0.22 & 0.30 & 0.10 & 0.24 & $0 \cdot 10$ & 0.45 & 0.20 & 0.50 \\
\hline $\mathrm{P}_{2} \mathrm{O}_{5}$ & 0.15 & $0 \cdot 30$ & 0.18 & 0.12 & 0.48 & $0 \cdot 30$ & 0.68 & $0 \cdot 31$ & $0 \cdot 25$ & 0.40 & 0.25 \\
\hline Total & 98.97 & 100.59 & $102 \cdot 46$ & 99.56 & $98 \cdot 78$ & 99.74 & $99 \cdot 73$ & 99.04 & $101 \cdot 30$ & $99 \cdot 56$ & 99.73 \\
\hline
\end{tabular}




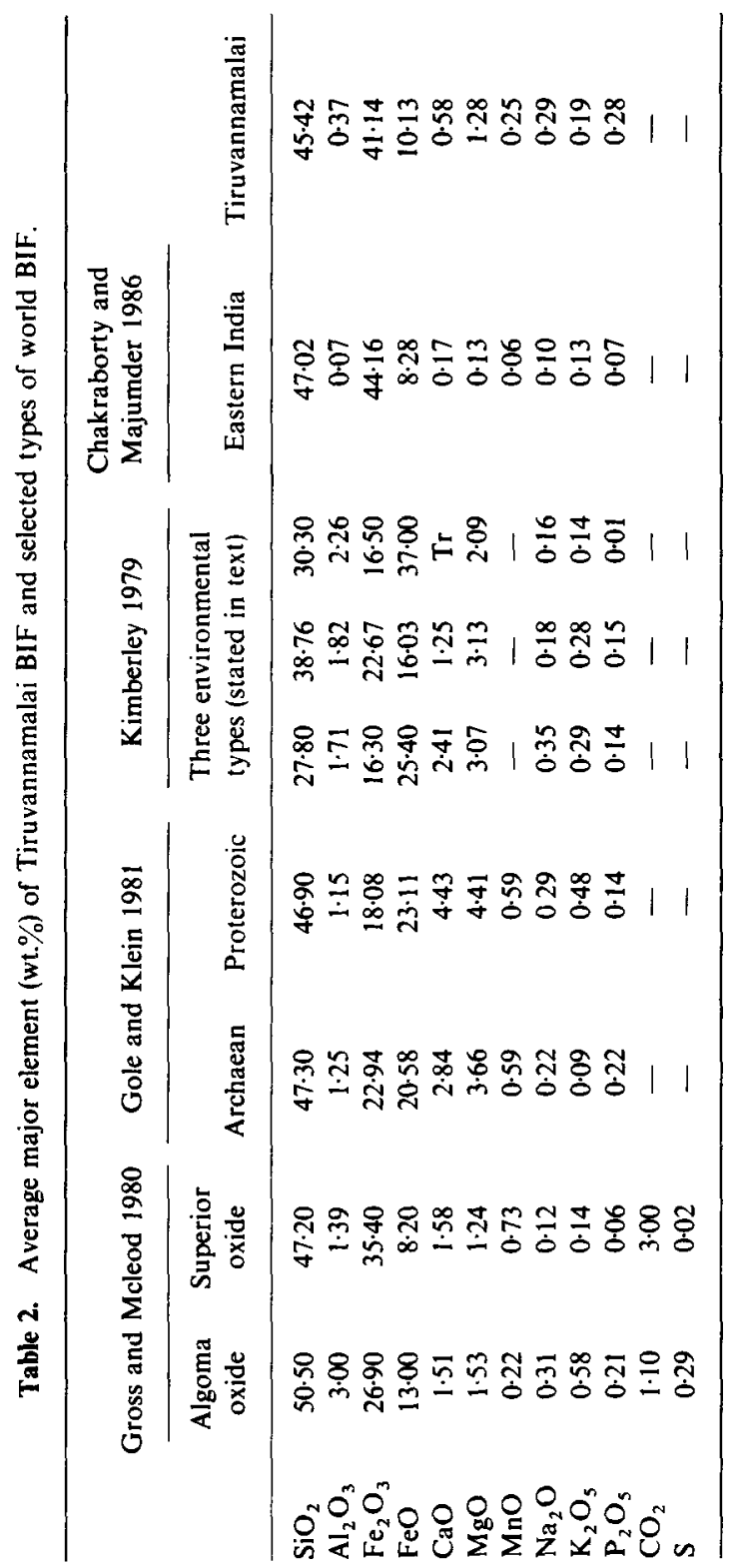


Magnetite-quartzite contain mainly magnetite without any ilmenite and the alteration products are Goethite and Limonite.

\section{Chemistry}

Whole rock chemical analysis of magnetite-quartzite of Tiruvannamalai area is given in table 1. In table 2 their average chemical composition is compared with that of Archaean and proterozoic iron formations of Gole and Klein, (1981), Algoma and superior oxide facies iron formations of Gross and Mcleod (1980), three environmental types (shallow volcanic platform iron formations (SVOPIF) metazoanpoor extensive chemical sediment rich sea iron formations (MECS-IF) and sandy clayey and oolitic shallow inland sea iron formations (SCDS-IF)) of Kimberly (1979) and eastern India BIF of Chakraborty and Majumder (1986). The absence of $\mathrm{CO}_{2}$ and $S$ in the analysis supplement due to lack of carbonates and sulphides in petrographic observations and low values of $\mathrm{Al}_{2} \mathrm{O}_{3}, \mathrm{CaO}$ and $\mathrm{MgO}$ in Tiruvannamalai BIF are noticeably significant in their difference. The proportions of $\mathrm{CaO}+\mathrm{MgO}, \mathrm{Fe}$ (total) and $\mathrm{SiO}_{2}$ and the proportions of $\mathrm{Al}_{2} \mathrm{O}_{3}, \mathrm{SiO}_{2}$ and $\mathrm{Fe}_{2} \mathrm{O}_{3}$, when plotted in triangular diagrams of Lepp and Goldich (1964) and Govett (1966) respectively, the BIF of Tiruvannamalai area clearly fall within the precambrian field (figures 1 and 2).

\section{Discussion}

Various hypotheses have been put forward to explain the origin of BIF. The trace elements in BIF and associated rocks are often considered reliable to interpret the physicochemical conditions of deposition and to predict the probable source of materials. Anjaneya Sastry and Krishna Rao (1970), Frietsch (1970), Majumdar et al (1982) and Davy (1983) reported low proportions of $\mathrm{Co}, \mathrm{Cr}, \mathrm{Ti}, \mathrm{V}$ and $\mathrm{Ni}$ in iron

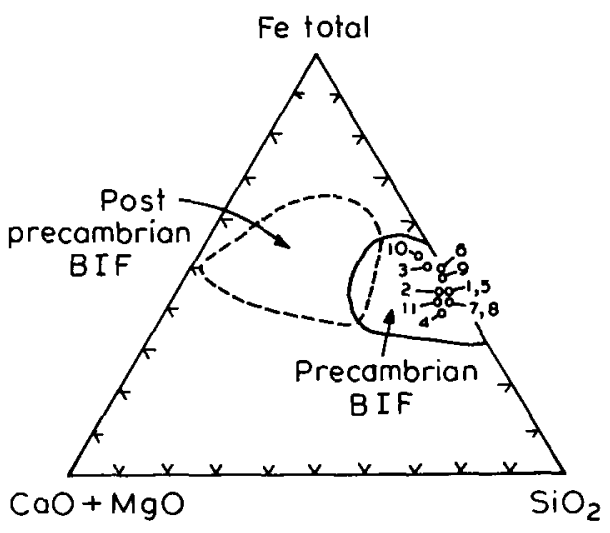

Figure 1. Composition of Tiruvannamalai BIF (after Lepp and Goldich 1964). 


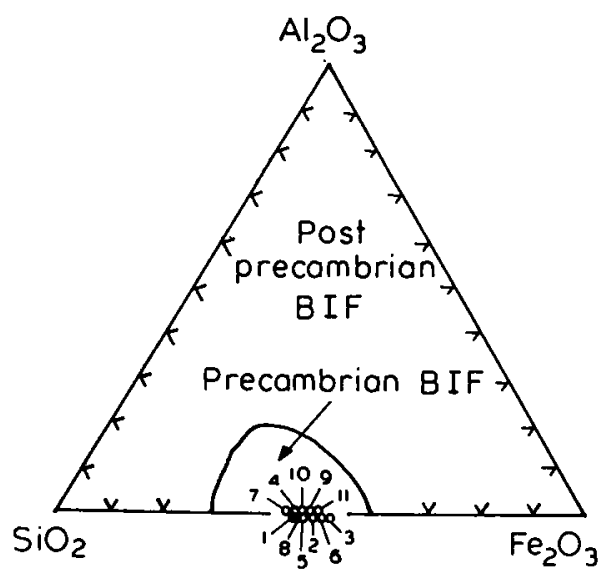

Figure 2. Composition of Tiruvannamalai BIF (after Govett 1966).

formations of sedimentary origin. Their high concentration in magnetites from known igneous formations has been reported by Wager and Mitchell (1951), Howie (1955), Gjelsvike (1957), Wilkinson (1959), Kisvarsanyi and Proctor (1967) and Schock (1979). Subba Reddy and Prasad (1982) reported low concentration of ferride group of trace elements in magnetites of magnetite-quartzite and their high concentration in magnetites of pyroxens granulites suggesting metasedimentary and metavolcanic origin respectively. The ultimate source of chemical components of BIF is generally attributed to volcano-sedimentary process (Alexandrov 1973; Beukes 1973; Quade 1976) but rarely to magmatism (Alexandrov 1973). The volcanism associated with the formation of acid and basic metavolcanics may be the source of iron and silica of magnetite-quartzite of Tiruvannamalai. Similar exhalative models were given by Simonsen (1985) and Gross (1986). The oldest BIF in the world, Isua of West Greenland were considered to be deposited in a submarine exhalative environment (Appel 1980). Since the Tiruvannamalai BIF occurs in a similar geologic setting as that of Isua (Windley 1984) it is possible that an exhalative process may be involved in their formation.

\section{Acknowledgements}

The authors are extremely thankful to Prof. C V R K Prasad for critically going through the manuscript which resulted in substantial improvement.

\section{References}

Alaxandrov A E 1973 The precambrian banded iron formation of the Soviet Union; Econ. Geol. 68 $1035-1062$

Anjaneya Sastry E and Krishna Rao J S R 1970 Ore microscopic X-ray and trace elemental studies of few iron ores from South India; J. Geol. Soc. India 11 242-247

Appel P W U 1980 On the early Archaean Isua formation, West Greenland; Precambrian Res. 11 73-87

Beukes N J 1973 Precambrian iron formations of southern Africa; Econ. Geol. 68 960-1004 
Chakraborty K L and Majumder T 1986 Geological aspects of the banded iron formation of Bihar and Orissa; J. Geol. Soc. India 28 109-133

Davy R 1983 Iron formation: facts and problems (eds) A F Trendall and R C Moriss (Amsterdam: Elsevier) 325-343

Frietsch R 1970 Trade elements in the magnetite and hematite; Sveriges. Geol. Unders. Arsbok 64 1-136

Gjelsvike T 1957 Geochernical and mineralogical investigation of titaniferous iron ores, West coast of Norway; Econ. Geol. 52 482-498

Gole M J and Klein C 1981 Banded iron formation through much of precambrian time; J. Geol. Soc. India $89169-183$

Govett G J S 1966 Origin of banded iron formations; Geol. Soc. Am. Bull. 77 1191-1211

Gross G A and Mcleod C R 1980 A preliminary assessment of the chemical composition of iron formation in Canada; Can. Miner. 18 223-229

Gross G A 1986 The metallogenic significance of iron-formation and related strata for rocks; J. Geol. Soc. India 28 92-108

Howie R A 1955 The geochemistry of the charnockite series of Madras, India; Trans. R. Soc. Edin 62 725-765

Kimberely M M 1979 Paleoenvironmental classification of iron-formation; Econ. Geol. $73215-229$

Kisvarsanyi G and Proctor P D 1967 Trace element content of magnetites and hematites, southeast Missouri iron metallogenic province, USA; Econ. Geol. $62442-470$

Lepp H and Goldich S 1964 Origin of precambrian iron formation; Econ. Geol. 59 1025-1060

Majumder T, Chakraborty K L and Bhattacharya A 1982 Geochemistry of banded iron formation of Orissa, India; Miner. Deposita 17 107-118

Prasad C V R K, Subba Reddy N and Windley B F 1982 Iron formations in Archaean granulite-gneiss belts with special reference to southern India; J. Geol. Soc. India $23112-122$

Quade H 1976 Genetic problems and environmental features of Volcano sedimentary iron ore deposits of the Lakn-Dill type; in Handbook of Strata sound stratification ore deposits (ed.) K H Wolf (Amsterdam: Elsevier) vol. 7 255-294

Radhakrishna B P 1985 Precambrian banded iron formation of India; Proc. of group discussion held at Dharwad, May 1985; J. Geol. Soc. India 26 825-832

Schock H H 1979 Distribution of rare earths and other trace elements in magnetites; Chem. Geol. 26 119-135

Simonsen B M 1985 Sedimentalogical constraints on the origin of precambrian iron formations; Geol Soc. Am. Bull. 96 244-252

Subba Reddy N and Prasad C V R K 1982 Trace element studies and origin of magnetite-quartzites of Tamil Nadu; J. Geol. Soc. India 23 80-85

Wager L R and Mitchell R L 1951 The distribution of trace elements during strong fractionation of basic magma-a further study of Skaerguard intrusion, East Greenland; Geochim. Cosmochim. Acta 16 123-150

Wilkinson J F G. 1959 The geochemistry of a differentiated teschenite sill near Gunnedah, New South Wales; Geochim. Cosmochim. Acta 16 125-150

Windley B F 1984 The evolving continents (New York: John Wiley) 